\title{
ANALISIS SIKAP ANGGOTA KOPERASI TERHADAP ATRIBUT-ATRIBUT JASA PELAYANAN PADA KOPERASI “SEJAHTERA” DI PURWOKERTO
}

\author{
P. Edi Sumantri \\ Mahasiswa Program Doktor Ilmu Manajemen Unversitas Jenderal Soedirman
}

\begin{abstract}
ABSTRAK
Penelitian ini bertujuan untuk mengetahui dan menganalisis sikap anggota koperasi terhadap atribut jasa pelayanan yang diberikan oleh pengurus kepada anggota koperasi. Variabel dalam penelitian ini meliputi Reliability, responsiveness, assurance, emphaty dan tangibles yang digunakan dengan cara membandingkan antara harapan dan keyakinan melalui metode analisis Multiatribute Attitude Model" (MAM). Hasil dari Penelitian menyatakan bahwa Sikap anggota koperasi terhadap atribut jasa pelayanan masuk dalam kategori sangat baik, sedangkan atribut yang paling dominan harus diperhatikan menurut anggota koperasi adalah atribut reliability. Implikasi dalam penelitian ini yaitu: sebaiknya pengurus koperasi memperhatikan atribut-atribut reliability, assurance, responsiveness, tangibles dan emphaty, serta atribut reliability menjadi atribut yang diprioritaskan oleh pengurus koperasi, yang berkaitan dengan kemampuan pengurus dalam memberikan pelayanan dengan segera dan memuaskan sesuai dengan yang telah dijanjikan.
\end{abstract}

Kata kunci : reliability, assurance, responsiveness, tangibles dan emphaty

\section{Pendahuluan}

Keberhasilan organisasi atau perusahaan ditentukan oleh berbagai macam faktor diantaranya bentuk pelayanan yang diberikan kepada semua elemen yang berhubungan dengan organisasi tersebut. Pemberian layanan (service delivery) adalah suatu hal yang menentukan tercapainya tujuan organisasi tersebut. Pelayanan yang diberikan dengan baik oleh organisasi atau perusahaan akan menciptakan kepuasan yang dirasakan oleh banyak pihak dan akan menimbulkan kepercayaan yang tinggi pada organisasi tersebut. Kepuasan Pelanggan menurut Kotler (2005) adalah perasaan senang atau kecewa seseorang yang berasal dari perbandingan antara kesannya terhadap kinerja atau hasil suatu produk dan harapan-harapannya. Kepuasan dari kualitas jasa dipengaruhi oleh variable yang dirasakan (perceived service) dan variabel yang diharapkan (expected service). Oliver (1980) dalam J. Supranto, (2003) menyatakan bahwa kepuasan adalah perasaan seseorang setelah membandingkan kinerja/hasil yang dirasakannya dengan harapannya. Jadi, jika kinerja pelayanan dari suatu organisasi berada di bawah harapan maka akan terjadi ketidakpuasan, sebaliknya apabila kinerja memenuhi atau diatas harapan maka kepuasan akan dirasakan.

Koperasi adalah suatu organisasi ekonomi yang berwatak sosial yang menempatkan unsur manusia lebih tinggi dari unsur modal tercermin dari hak suara anggota dalam rapat dan pengambilan keputusan dengan partisipasi dari seluruh anggota koperasi sehingga pelayanan harus menjadi prioritas untuk diperhatikan oleh pengurus koperasi sehingga yang diharapkan oleh seluruh anggotanya dapat terpenuhi. Tingkat partisipasi anggota koperasi dipengaruhi oleh beberapa faktor seperti karakteristik anggota, keadaan lingkungan, dan tingkat pelayanan koperasi kepada seluruh anggota. Karakteristik anggota merupakan dasar bagi kelangsungan kegiatan dan kehidupan koperasi sehingga etos kerja yang tinggi, tanggung jawab dan kejujuran 
merupakan hal penting dalam peningkatan sumber daya manusia sebagai pengelola maupun sebagai anggota yang bertanggung jawab.

Dalam dinamika aktivitas serta besarnya tuntutan anggota untuk memperoleh kepuasan yang lebih besar, sementara kemampuan pengurus koperasi terbatas maka kemungkinan pengurus koperasi tidak dapat merespon semua yang menjadi keinginan anggota, dengan kondisi ini maka timbullah kesenjangan antara harapan dengan realitasnya. Tantangan lain yang sering dihadapi oleh koperasi dalam era globalisasi adalah menghadapi para pemodal besar (kapitalis) yang menguasai kegiatan usaha penting di berbagai bidang termasuk bidang-bidang yang menjadi basis utama dalam kegiatan di koperasi. Kapitalisme berpengaruh cukup kuat, terbukti dengan adanya sistem monopoli dan kartel, sehingga tidak memberi peluang kepada para pengusaha kecil termasuk koperasi yang harus menyediakan sarana produksi. Hal ini mengakibatkan posisi tawar koperasi menjadi sangat lemah, yang pada gilirannya berdampak pada keterbatasan pendapatan dan kesejahteraan para anggotanya.

(http://pustaka.unpad.ac.id/wpcontent/uplo ads/2011/02/ partisipasi anggota dan dinamika perkembang.pdf)

Dalam memajukan koperasi, pelayanan merupakan salah satu hal yang harus diperhatikan agar bisa berkembang dengan baik. Menurut Husain Umar ada lima atribut atau standar dalam pelayanan yaitu reliability, responsiviness, assurance, emphaty, dan tangible. Reliability merupakan ketepatan pengurus koperasi dalam memenuhi janji kepada para anggotanya, sedangkan kesigapan karyawan dalam memberikan pelayanan kepada anggota disebut responsiviness, kesopan santunan dalam melayani anggota dikategorikan sebagai assurance, perhatian karyawan terhadap anggota disebut emphaty dan fasilitas fisik dari koperasi yang lengkap sebagai tangible.

Dalam menjalankan kegiatannya, koperasi "Sejahtera" di Purwokerto selalu berusaha untuk memberikan pelayanan yang prima. Hal ini sangat penting karena anggota adalah pemilik sekaligus sebagai pelanggan koperasi, namun hal ini tidak menjamin bahwa anggota akan setia memanfaatkan jasa pelayanan yang diberikan oleh koperasi. Dalam keadaan struktur pasar yang persaingannya sangat ketat, an ggota koperasi akan dengan mudah tergoda melakukan transaksi dengan pihak lain yang disebabkan karena pelayanan koperasi dirasa tidak memuaskan. Jadi pengurus koperasi harus dapat memberikan pelayanan prima bagi seluruh anggotanya agar merasa puas sehingga akan menjadi pelanggan setia bagi koperasi yang menjadi miliknya.

Setiap anggota yang memanfaatkan $\mathrm{j}$ asa pelayanan yang diberikan oleh koperasi pasti berharap memperoleh kepuasan. Kepuasan sering didefinisikan dari perspektif pengalaman anggota setelah menggunakan barang dan jasa yang diberikan oleh koperasi tersebut. Kepuasan anggota

adalah hasil penilaian dari

anggota bahwa produk atau pelayanan yang diberikan telah memberikan tingkat kenikmatan yang lebih atau kurang dari yang dibutuhkannya. Perasaan senang atau kecewa seseorang muncul setelah membandingkan antara kinerja atau hasil yang dirasakan dengan kinerja atau hasil yang diharapkan. Jika kinerja berada di bawah harapan maka anggota merasa tidak puas, jika kinerja memenuhi harapan maka anggota merasa puas, dan jika kinerja melebihi harapan maka pelanggan / anggota merasa sangat puas atau senang. Konsep kepuasan ini harus dipahami dan diupayakan oleh pengurus koperasi untuk selalu meningkatkan pelayanannya dalam usaha memberikan kepuasan kepada seluruh anggotanya. 
Faktor-faktor yang dapat membentuk harapan anggota diantaranya pengalaman pribadi ketika menggunakan jasa, mendapatkan informasi dari pengalaman orang lain, termasuk janjijanji yang diberikan oleh pengurus koperasi. Jika Anggota koperasi merasa puas dengan pelayanan yang diberikan oleh pengurus koperasi maka anggota tersebut biasanya akan menjadi duta promosi bagi anggota yang lainnya dan masyarakat pada umumnya, dengan demikian maka koperasi dapat berkembang lebih cepat termasuk apabila koperasi menggunakan alokasi dana untuk kegiatan promosi maka dana tersebut bisa ditekan agar lebih efisien. Dari uraian diatas maka beberapa hal menjadi permasalahan dalam penelitian ini yaitu:

1. Bagaimana sikap anggota koperasi terhadap atribut-atribut jasa pelayanan yang diberikan oleh pengurus di koperasi "Sejahtera" Purwokerto?

2. Atribut-atribut jasa pelayanan mana yang dirasakan paling penting menurut anggota koperasi "Sejahtera"di Purwokerto?

Penelitian ini menggunakan data yang diperoleh melalui kuesioner yang berhubungan dengan atribut-atribut jasa pelayanan, dibagikan kepada para anggota koperasi "Sejahtera" di Purwokerto.

\section{Tinjauan Pustaka}

1. Pengertian Pelayanan

Menurut Kotler (2005) pelayanan adalah setiap tindakan atau kegiatan yang dapat ditawarkan oleh suatu pihak kepada pihak lain, yang pada dasarnya tidak berwujud dan tidak mengakibatkan kepemilikan apapun. Untuk memberikan pelayanan yang baik ada tiga kunci pelayanan yaitu:

a. Kemampuan memahami kebutuhan dan keinginan pelanggan, termasuk didalamnya memahami tipe-tipe pelanggan b. Pengembangan database yang akurat dari para pesaing mencakup data kebutuhan dan keinginan setiap segmen pelanggan dan perubahan kondisi pesaing

c. Pemanfaatan informasi yang diperoleh dari riset pasar dalam suatu kerangka strategik.

Umar (2002) mengemukakan lima atribut dalam menentukan kualitas pelayanan yang menjadi terjaminnya kepuasan pelanggan, pengguna atau pembeli jasa tersebut yaitu: Reliability, Responsiveness, Assurance, Emphaty, Tangibles. Mengingat pentingnya pelanggan, menurut Supranto (2003), ada beberapa hal yang harus disadari oleh pihak perusahaan bahwa:

a. Pelanggan adalah orang yang paling penting bagi perusahaan

b. Pelanggan adalah obyek yang dapat memberikan keuntungan bagi perusahaan

c. Pelanggan bukanlah lawan bicara yang perlu diajak berdebat, maka pihak yang menang haruslah pelanggan, pelanggan adalah raja, sekali ia kalah dalam berargumentasi, maka ia akan pindah ke perusahaan lain

d. Pelanggan adalah manusia biasa yang memiliki perasaan senang, benci, bosan, cinta dan adakalanya mempunyai prasangka yang tidak beralasan

e. Pelanggan dalam usahanya mendapatkan pelayanan selalu ingin didahulukan, diperhatikan dan ingin diistimewakan, serta sekali-kali tidak ingin diremehkan begitu saja.

Pelayanan koperasi akan menjadi sesuatu yang bermanfaat apabila

didasarkan kepada kepentingan anggotanya. Koperasi harus mencurahkan perhatian kepada hal-hal yang dianggap penting oleh anggota. Menurut Kotler, kualitas harus dimulai dari kebutuhan pelanggan dan berakhir pada persepsi konsumen. Hal ini berarti 
citra kualitas yang baik bukanlah berdasarkan sudut pandang atau persepsi penyedia jasa, melainkan berdasarkan sudut pandang atau persepsi konsumen. Menurut Parasuraman, Zeithaml, dan Berry (1988), dalam mengembangkan pengukuran kualitas jasa/pelayanan adalah alat ukur kualitas layanan yaitu SERVQUAL, yaitu: Tangibles atau Ketampakan Fisik, Reliability atau Kompetensi petugas pelayanan, Responsivitas atau Daya Tanggap petugas pelayanan, Assurance atau Kepastian (Jaminan) Pelayanan, Empathy.

Keunggulan yang dilihat dari setiap perusahaan jasa adalah bagaimana mereka mampu memberikan pelayanan yang berkualitas bagi pelanggan atau konsumennya. Wijaya (2011: 11) menyatakan bahwa kualitas produk atau jasa (pelayanan) didefinisikan sebagai keseluruhan gabungan karakteristik produk dan jasa yang dihasilkan dari pemasaran, rekayasa, produksi, dan pemeliharaan yang membuat produk dan jasa tersebut dapat digunakan memenuhi harapan pelanggan. Kualitas pelayanan dapat diukur dengan membandingkan antara persepsi konsumen atas jasa yang mereka terima dengan harapan terhadap kinerja jasa tersebut (persepsion expectation).

\section{Perilaku Anggota}

Pada dasarnya hal-hal yang diharapkan oleh seluruh anggota koperasi tidaklah berbeda dengan harapan seorang konsumen dalam menentukan kegiatannya dalam melakukan transaksi. Memahami perilaku konsumen merupakan dasar dalam mengelola kegiatan pemasaran. Menurut Schiffman dan Kanuk yang dimaksud dengan perilaku konsumen adalah perilaku konsumen yang ditujukan melalui pencarian, pembelian, penggunaan, pengevaluasian, dan penentuan produk dan jasa yang mereka harapkan dapat memuaskan kebutuhan mereka. Anoraga (2000) menyebutkan lima tahap dalam proses pengambilan keputusan yang umum untuk membeli yang umum dilakukan seseorang yaitu:

a. Pengenalan kebutuhan

b. Proses informasi konsumen

c. Evaluasi produk/merk

d. Pembelian

e. Sekali konsumen melakukan pembelian maka evaluasi pasca pembelian akan terjadi. Jika kinerja produk sesuai dengan harapan konsumen maka konsumen akan puas dan berlaku sebaliknya.

Kepuasan dari konsumen menjadi perhatian utama, dimana konsumen akan dapat menjadi pelanggan yang akan bertindak sebagai agen dari perusahaan tersebut apabila konsumen dapat terpuaskan, demikian juga yang terjadi pada koperasi, kepuasan dari anggota menjadi hal yang sangat penting untuk bisa meningkatkan loyalitas seluruh anggota-anggotanya.

\section{Kepuasan Konsumen}

Menurut Umar (2002) kepuasan adalah tingkat perasaan konsumen setelah membandingkan dengan harapannya. Pengertian tersebut menunjukkan bahwa konsumen akan merasa puas apabila produk berupa barang maupun jasa yang dibeli sesuai dengan yang diharapkan atau memenuhi kebutuhan dan keinginan dari konsumen. Konsumen yang terpuaskan selanjutnya dapat menjadi pelanggan. Faktor-faktor yang dapat mempengaruhi kepuasan pelanggan adalah mutu produk dan pelayanannya, kegiatan penjualan, pelayanan setelah penjualan dan nilai-nilai perusahaan.

Persaingan yang semakin ketat, dimana semakin banyak produsen yang 
terlibat dalam pemenuhan kebutuhan dan keinginan konsumen, menyebabkan setiap perusahaan harus menempatkan orientasi pada kepuasan pelanggan sebagai tujuan utama. Hal ini tercermin dari semakin banyaknya perusahaan yang menyertakan komitmennya terhadap kepuasan pelanggan dalam pernyataan misalnya iklan, public relation release. Dewasa ini semakin diyakini bahwa kunci utama untuk memenangkan persaingan adalah memberikan nilai dan kepuasan kepada pelanggan melalui penyampaian produk dan jasa yang berkualitas dengan harga yang bersaing.

Pada dasarnya tujuan dari suatu bisnis adalah untuk menciptakan para pelanggan yang merasa puas. Terciptanya kepuasan pelanggan dapat memberikan beberapa manfaat, diantaranya hubungan Antara perusahaan dan pelanggannya menjadi harmonis, memberikan dasar yang baik bagi pembelian ulang dan terciptanya loyalitas pelanggan dan membentuk suatu rekomendasi dari mulut ke mulut yang menguntungkan bagi perusahaan (Tjiptono, 2008).

Dalam koperasi, kepuasan lebih banyak didefinisikan dari perspektif pengalaman anggota setelah menggunakan barang dan jasa. Konsep kepuasan ini harus dipahami dan diupayakan oleh pengurus koperasi. Harapan anggota terhadap pelayanan koperasi harus diketahui oleh pengurus koperasi. Faktor-faktor yang dapat membentuk harapan anggota:
a. Pengalaman pribadi
ketika menggunakan jasa.
b. Mendapatkan informasi dari pengalaman orang lain.
c. Janji-janji yang diberikan oleh Pengurus koperasi

4. Pengertian sikap dan Ciri-ciri sikap
Sikap merupakan status mental seseorang. Sikap adalah kecenderungan yang dipelajari dalam perilaku dengan cara yang menyenangkan atau tidak menyenangkan terhadap suatu obyek (Schiffman dan Kanuk, 2004). Sikap timbul dari adanya interaksi manusia dengan obyek tertentu. Terbentuknya sikap akan dipengaruhi oleh bermacam-macam faktor, dalam hal ini lingkungan psikologis, sosial, mempunyai pengaruh yang besar dalam hubungannya dengan tingkah laku seseorang sebagai anggota masyarakat. Dengan mengetahui sikap karyawan dapat mempermudah pimpinan dalam mengambil kebijaksanaan untuk mengetahui gambaran tentang tingkah laku seorang karyawan sehingga pimpinan mengerti motif karyawan dalam menyelesaikan tugas pekerjaannya.

Pendapat mengenai batasan sikap adalah kecenderungan yang bersikap positif atau negatif yang berhubungan dengan obyek psikologi. Obyek psikologi meliputi symbol, kata-kata, slogan, orang, lembaga dan ide. Orang dikatakan memiliki sikap positif terhadap suatu obyek psikologis apabila ia suka, sebaliknya orang dikatakan negative terhadap obyek psikologis apabila ia tidak suka, sedangkan hubungan sikap dengan motif yaitu merupakan pandangan atau sikap perasaan yang disertai dengan kecenderungan untuk bertindak sesuai dengan sikap terhadap obyek (Partini, 1995).

Dari pendapat-pendapat diatas maka dapat disimpulkan bahwa sikap adalah keadaan dalam diri untuk bertindak, menyertai manusia dengan perasaan-perasaan tertentu dalam menanggapi obyek dan tertentu atas dasar pengalaman-pengalaman. Untuk lebih jelas mengenai pengertian sikap, perlu diperhatikan komponen- 
komponen sikap dibawah ini (Partini, 1995):

a. Komponen Kognitif

b. Komponen Afektif

c. Komponen Konatif atau perilaku

Sikap menentukan jenis atau tabiat tingkah laku dalam hubungannya dengan perangsang yang relevan, orang-orang atau kejadian. Adapun ciri-ciri sikap adalah sebagai berikut:

a. Sikap itu dipelajari

b. Memiliki kestabilan

c. Personal

d. Berisi kognisi dan afeksi

e. Approach-avoidance directionality

Sikap konsumen terbentuk sebagai hasil dari kontak langsung dengan obyek sikap, fakor lingkungan atau faktor yang memiliki pengaruh kuat pada pembentukan sikap dengan berbagai jenis, jumlah, kualitas, informasi dan pengalaman yang tersedia bagi konsumen. Sikap seorang predisposisi (keadaan mudah terpengaruh) untuk memberikan tanggapan terhadap rangsangan lingkungan yang dapat memulai atau membimbing tingkah laku orang tersebut. Sikap merupakan hasil dari faktor genetis dan proses belajar dan selalu berhubungan dengan suatu obyek atau produk yang dihadapinya. Sikap biasanya memberikan penilaian (menerima atau menolak) terhadap produk dan proses belajar baik dari pengalaman ataupun dari yang lainnya (Swasta dan Handoko, 1997).

\section{Hipotesis}

a. Sikap anggota koperasi terhadap atribut-atribut jasa pelayanan pada koperasi "Sejahtera" di Purwokerto, baik

b. Atribut Emphaty yang paling dominan dari atribut-atribut yang ada pada atribut jasa pelayanan pada koperasi "Sejahtera" di Purwokerto.

\section{Metode Penelitian dan Analisis}

Penelitian ini menggunakan metode survey, dengan obyek anggota koperasi "Sejahtera" di Purwokerto.

Definisi operasional variable meliputi:

1. Harapan anggota koperasi "Sejahtera" di Purwokerto

a. Reliability, yaitu harapan anggota koperasi terhadap kemampuan pengurus dalam memberikan pelayanan dengan segera dan memuaskan sesuai dengan yang telah dijanjikan. Indikatornya ketepatan pengurus dalam memenuhi janji

b. Responsiveness, harapan anggota koperasi terhadap kemampuan untuk membantu para anggota dan memberikan pelayanan sebaik mungkin

c. Assurance, harapan anggota koperasi terhadap pengetahuan dan kesopansantunan para pengurus koperasi serta kemampuan mereka untuk menumbuhkan rasa percaya para anggotanya dengan indikator kesopan santunan dalam melayani

d. Emphaty, harapan anggota koperasi terhadap perhatian yang tulus dari pengurus koperasi yang diberikan kepada anggota serta adanya kemudahan dalam melakukan hubungan komunikasi yang baik dan pemahaman atas kebutuhan anggota. Indikatornya perhatian karyawan terhadap anggota

e. Tangibles, harapan anggota koperasi terhadap penampilan fisik produk jasa seperti fasilitas fisik serta fasilitas layanan lainnya. Indikatornya fasilitas fisik koperasi

2. Keyakinan anggota koperasi "Sejahtera" di Purwokerto

a. Reliability, yaitu harapan anggota koperasi terhadap kemampuan pengurus dalam memberikan pelayanan dengan segera dan memuaskan sesuai dengan yang telah dijanjikan. Indikatornya 
ketepatan pengurus dalam memenuhi janji

b. Responsiveness, harapan anggota koperasi terhadap kemampuan untuk memmbantu para anggota dan memberikan pelayanan sebaik mungkin

c. Assurance, harapan anggota koperasi terhadap pengetahuan dan kesopansantunan para pengurus koperasi serta kemampuan mereka untuk menumbuhkan rasa percaya para anggotanya. Indikatornya kesopan santunan dalam melayani

d. Emphaty, harapan anggota koperasi terhadap perhatian yang tulus dari pengurus koperasi yang diberikan kepada anggota serta adanya kemudahan dalam melakukan hubungan komunikasi yang baik dan pemahaman atas kebutuhan anggota. Indikatornya perhatian karyawan terhadap nasabah

e. Tangibles, harapan anggota koperasi terhadap penampilan fisik produk jasa seperti fasilitas fisik serta fasilitas layanan lainnya. Indikatornya fasilitas fisik koperasi

Dalam menganalisis data kualitatif yang diperoleh dari kuesioner dilakukan melalui (Singarimbun dan Effendi, 1995): editing, coding, skoring dengan bobot jawaban mulai dengan sangat setuju (SS) skor : 5 sampai dengan sangat tidak setuju (STS) skor: 1.

Pengujian Validitas dilakukan untuk menunjukkan sejauh mana ketepatan dan kecermatan suatu alat ukur dalam melakukan fungsi ukurnya (Umar, 2002). Menurut Arikunto instrumen dikatakan baik apabila memenuhi dua syarat, yaitu valid dan reliabel. Pengujian validitas instrumen penelitian dilakukan dengan mengkorelasikan masing-masing pernyataan dengan skor total memakai rumus korelasi product moment.
Pengujian Reliabilitas dilakukan untuk menunjukkan konsistensi suatu alat pengukur dalam mengukur gejala yang sama dengan menghitung korelasi antara belahan ganjil-genap dengan rumus korelasi product moment (Umar, 2002). Hasilnya kemudian disubstitusikan ke dalam rumus Spearman Brown.

Multiatribute Attitude Model" (MAM) digunakan untuk menguji sikap terhadap atribut-atribut pelayanan. Dengan skala sikap yang terdiri dari lima interval maka perbedaan maksimum antara nilai ideal dan belief berada dalam rentang skala mulai dari sangat baik sampai dengan sangat tidak baik, jika makin kekiri maka sikap pengguna jasa yang ada adalah sangat baik dan sebaliknya (Del. I. Hawkins, et.al, 1983)

Sangat baik Baik Cukup Baik Kurang baik Sangat Tidak baik

\begin{tabular}{|c|c|c|c|}
\hline & & & \\
\hline 0 & 33,6 & \multicolumn{2}{c|}{67,2} \\
100,8 & 134,4 & 168
\end{tabular}

Gambar 1: Letak skala interval

Untuk menguji dominasi dari atributatribut reliability, responsiveness, assurance, emphaty, dan tangibles dianalisis dengan cara mencari nilai absolut dari atribut-atribut tersebut.

\section{Hasil Penelitian dan Pembahasan}

Gambaran penelitian menunjukkan jumlah responden laki-laki orang $(72,09 \%)$, perempuan 12 orang $(27,91 \%)$, dan rentang usia antara $35-45$ tahun sebanyak 18 orang $(41,86 \%)$, lebih dari 45 tahun berjumlah 25 orang $(58,14$ \%) serta dilihat dari tingkat pendidikan: SMA 23 orang (53,49 \%), SD dan SMP: 2 orang $(4,65 \%)$, Diploma 4 orang $(9,30 \%)$ dan sarjana 12 orang $(27,91 \%)$

Pengujian validitas yang dilakukan dengan software SPSS for window 16, diperoleh hasil pengujian yang dapat dilihat pada tabel berikut: 
Tabel 1: Validitas butir pertanyaan dari variabel ideal terhadap atribut-atribut jasa pelayanan di Koperasi "Sejahtera" Purwokerto

\begin{tabular}{|l|c|c|c|}
\hline \multicolumn{1}{|c|}{ Pertanyaan } & R hitung & R tabel & Keterangan \\
\hline Reliability & 0,691 & 0,361 & Valid \\
Responsiveness & 0,588 & 0,361 & Valid \\
Assurance & 0,621 & 0,361 & Valid \\
Emphaty & 0,718 & 0,361 & Valid \\
Tangibles & 0,615 & 0,361 & Valid \\
\hline
\end{tabular}

Sumber: Data Primer diolah

Tabel 2: Validitas butir pertanyaan dari variabel belief terhadap atribut-atribut jasa pelayanan di Koperasi "Sejahtera" Purwokerto

\begin{tabular}{|l|c|c|c|}
\hline \multicolumn{1}{|c|}{ Pertanyaan } & R hitung & R tabel & Keterangan \\
\hline Reliability & 0,754 & 0,361 & Valid \\
Responsiveness & 0,749 & 0,361 & Valid \\
Assurance & 0,718 & 0,361 & Valid \\
Emphaty & 0,818 & 0,361 & Valid \\
Tangibles & 0,612 & 0,361 & Valid \\
\hline
\end{tabular}

Sumber: Data Primer diolah

Dari tabel 1 dan 2 dapat diketahui hasil perhitungan pengujian validitas untuk butir-butir pertanyaan dari variabel "ideal" dan "belief" diperoleh $\mathrm{R}$ hitung untuk setiap pertanyaan dari variabel ideal nilainya lebih besar dari $\mathrm{R}$ tabel, maka dapat diartikan bahwa variabel ideal terhadap atribut-atribut pelayanan tersebut telah valid.
Pengujian reliabilitas dilakukan dengan menggunakan alpha cronbach. dengan menggunakan SPSS for window. Untuk nilai dari masing-masing variabel "ideal" dan "belief" terhadap atributatribut yang terdapat pada jasa pelayanan dapat dilihat dalam tabel 6 sebagai berikut:

Tabel 3: Reliabilitas variabel ideal dan belief terhadap atribut-atribut jasa pelayanan di Koperasi "Sejahtera" Purwokerto

\begin{tabular}{|l|c|c|c|}
\hline \multicolumn{1}{|c|}{ Variabel } & R hitung & R tabel & Keterangan \\
\hline $\begin{array}{l}\text { Ideal terhadap atribut-atribut yang } \\
\text { terdapat pada jasa pelayanan }\end{array}$ & 0,754 & 0,361 & Reliabel \\
$\begin{array}{l}\text { Belief terhadap atribut-atribut yang } \\
\text { terdapat pada jasa pelayanan }\end{array}$ & 0,785 & 0,361 & Reliabel \\
\hline
\end{tabular}

Sumber: Data Primer diolah

Dari tabel 3 dapat dilihat bahwa nilai-nilai $r$ hitung semuanya lebih besar dari $\mathrm{r}$ tabel dengan $\mathrm{N}=30$ dan level of significance $95 \%$ atau $\alpha=0,05$, sehingga dapat dikatakan bahwa alat ukur yang digunakan dalam penelitian ini memenuhi syarat reliabilitas.

Untuk mengetahui harapan anggota koperasi "Sejahtera" terhadap jasa pelayanan yang diberikan oleh para pengurusnya dapat diketahui hasilnya dari dimensi reliability dengan indikator kemampuan pengurus dalam memberikan pelayanan dengan segera dan memuaskan sesuai yang telah dijanjikan dari 43 responden sebanyak 4 orang $(9,3 \%)$ menyatakan sangat setuju, $16(37,3 \%)$ orang menyatakan setuju, 22 orang 
$(51,2 \%)$ netral, 1 orang $(2,3 \%)$ tidak setuju, dan tidak ada yang menyatakan sangat tidak setuju. Responsiveness, dengan indikator kemampuan pengurus dalam membantu memberikan pelayanan sebaik mungkin, dari 43 responden, sebanyak 8 orang $(18,6 \%)$ menyatakan sangat setuju, $23(23,3 \%)$ orang menyatakan setuju, 24 orang $(55,8 \%)$ netral, 1 orang $(2,3 \%)$ tidak setuju, dan tidak ada yang menyatakan sangat tidak setuju. Assurance, dengan indikator pengetahuan dan kesopansantunan pengurus yang menumbuhkan rasa percaya para anggota koperasi, dari 43 responden sebanyak 8 orang $(18,6 \%)$ menyatakan sangat setuju, $14 \quad(32,6 \%)$ orang menyatakan setuju, 20 orang $(46,5 \%)$ netral, 1 orang $(2,3 \%)$ tidak setuju, dan tidak ada yang menyatakan sangat tidak setuju. Emphaty, dengan indikator perhatian yang tulus dari pengurus, serta ada kemudahan dalam melakukan hubungan komunikasi, dari 43 responden sebanyak 9 orang $(20,9 \%)$ menyatakan sangat setuju, $16 \quad(37,2 \%)$ orang menyatakan setuju, 16 orang $(37,2 \%)$ netral, 2 orang $(4,7 \%)$ tidak setuju, dan tidak ada yang menyatakan sangat tidak setuju. Tangibles, dengan indikator fasilitas fisik yang memuaskan untuk menunjang kegiatan di koperasi, dari 43 responden, sebanyak 9 orang $(20,9$ $\%)$ menyatakan sangat setuju, 13 (30,2\%) orang menyatakan setuju, 13 orang $(30,2 \%)$ netral, 8 orang $(18,6 \%)$ tidak setuju, dan tidak ada yang menyatakan sangat tidak setuju.

Untuk mengetahui kenyataan / belief dari jasa pelayanan yang diberikan oleh koperasi "Sejahtera" Purwokerto, digunakan lima indikator. Nilai variabel kenyataan (belief) jasa pelayanan butir pertanyaan reliability, pengurus mampu memberikan pelayanan dengan segera dan memuaskan sesuai dengan yang telah dijanjikan, dari 43 responden, sebanyak 3 orang $(7,0 \%)$ menyatakan sangat setuju, $13(30,2 \%)$ orang menyatakan setuju, 22 orang $(51,2 \%)$ netral, 3 orang $(7 \%)$ tidak setuju, dan 2 orang $(4,7 \%)$ menyatakan sangat tidak setuju. Responsiveness, pengurus mampu membantu para anggota koperasi dengan memberikan pelayanan sebaik mungkin dari 43 responden, sebanyak 5 orang $(11,6 \%)$ menyatakan sangat setuju, $12(27,9 \%)$ orang menyatakan setuju, 19 orang (44,2\%) netral, 3 orang $(7,0 \%)$ tidak setuju, 4 orang $(9,3 \%)$ menyatakan sangat tidak setuju. Assurance, pengetahuan dan kesopansantunan pengurus akan menumbuhkan rasa percaya para anggota koperasi, dari 43 responden, sebanyak 5 orang $(11,6 \%)$ menyatakan sangat setuju, $14(32,6 \%)$ orang menyatakan setuju, 20 orang $(46,5 \%)$ netral, 4 orang $(9,3 \%)$ tidak setuju, dan tidak ada yang menyatakan sangat tidak setuju. Emphaty, perhatian yang tulus dari pengurus, serta ada kemudahan dalam melakukan hubungan komunikasi dari 43 responden, sebanyak 6 orang $(14,0 \%)$ menyatakan sangat setuju, $15 \quad(34,9 \%)$ orang menyatakan setuju, 14 orang $(32,6 \%)$ netral, 5 orang $(11,6 \%)$ tidak setuju, dan 3 orang $(7,0 \%)$ yang menyatakan sangat tidak setuju. Tangibles, fasilitas fisik yang ada untuk menunjang kegiatan di koperasi memuaskan, dari 43 responden, sebanyak 6 orang $(14,0 \%)$ menyatakan sangat setuju, $11(25,6 \%)$ orang menyatakan setuju, 18 orang $(41,9 \%)$ netral, 7 orang $(16,3 \%)$ tidak setuju, dan 1 orang $(2,3 \%)$ yang menyatakan sangat tidak setuju.

\section{Pengujian hipotesis 1 (Multiatribute Attitude Model)}

Untuk mengetahui sikap anggota terhadap atribut-atribut jasa pelayanan pada koperasi "Sejahtera" Purwokerto digunakan metode analisis Multiatribute Attitude Model (MAM) dengan langkahlangkah sebagai berikut:

a. Menentukan bobot dan urutan
kepentingan
Urutan kepentingan yang
diberikan oleh anggota koperasi 
terhadap masing-masing atribut, dilakukan dengan menghitung selisih dengan yang lain dengan jumlah total antara urutan kepentingan yang satu bobot 43 .

Tabel 4 : Tingkat bobot (Wi)

\begin{tabular}{|c|c|c|}
\hline No. & Tingkat Kepentingan & Bobot \\
\hline 1 & $5 / 15 \times 43$ & 14,33 \\
2 & $4 / 15 \times 43$ & 11,46 \\
3 & $3 / 15 \times 43$ & 8,60 \\
4 & $2 / 15 \times 43$ & 5,73 \\
5 & $1 / 15 \times 43$ & 2,86 \\
\hline 15 & & 43,00 \\
\hline
\end{tabular}

Dari tabel 4 dapat dilihat pemberian bobot (Wi) bagi masingmasing atribut berdasarkan urutan kepentingan, dengan menjumlahkan urutannya sebagai berikut: $1+2+3+$ $4+5=15$ dengan jumlah bobot 43 dan besarnya bobot masing-masing urutan tingkat kepentingannya.

b. Menghitung ideal dan belief rata-rata dan selisihnya

Tabel 5: Perhitungan ideal dan belief rata-rata dan selisihnya

\begin{tabular}{|c|c|c|c|c|c|c|c|c|c|c|c|c|c|c|}
\hline \multirow{2}{*}{$\begin{array}{c}\text { Sikap } \\
\text { Konsumen }\end{array}$} & \multicolumn{5}{|c|}{ Ideal } & \multirow{2}{*}{ Total } & \multicolumn{5}{|c|}{ Belief } & \multirow{2}{*}{ Total } & \multirow{2}{*}{ Selisih } & \multirow{2}{*}{$\begin{array}{l}\text { Rang- } \\
\text { king }\end{array}$} \\
\hline & 5 & 4 & 3 & 2 & 1 & & 5 & 4 & 3 & 2 & 1 & & & \\
\hline \multicolumn{15}{|l|}{ 1. Realibility } \\
\hline Jumlah & 4 & 16 & 22 & 1 & 0 & 43 & 3 & 13 & 22 & 3 & 2 & & & \\
\hline Absolut & 20 & 64 & 66 & 2 & 0 & 152 & 15 & 52 & 66 & 6 & 2 & 141 & & \\
\hline Rata-rata & & & & & & 3,53 & & & & & & 3,28 & 0,25 & 3 \\
\hline \multicolumn{15}{|c|}{ 2. Responsiveness } \\
\hline Jumlah & 8 & 10 & 24 & 1 & 0 & 43 & 5 & 12 & 19 & 3 & 4 & & & \\
\hline Absolut & 40 & 40 & 72 & 2 & 0 & 154 & 25 & 48 & 57 & 6 & 4 & 140 & & \\
\hline Rata-rata & & & & & & 3,58 & & & & & & 3,26 & 0,32 & 4 \\
\hline \multicolumn{15}{|l|}{ 3. Assurance } \\
\hline Jumlah & 8 & 14 & 20 & 1 & 0 & 43 & 5 & 14 & 20 & 4 & 0 & & & \\
\hline Absolut & 40 & 56 & 60 & 2 & 0 & 158 & 25 & 56 & 60 & 8 & 0 & 149 & & \\
\hline Rata-rata & & & & & & 3,674 & & & & & & 3,465 & 0,209 & 2 \\
\hline \multicolumn{15}{|l|}{ 4. Emphaty } \\
\hline Jumlah & 9 & 16 & 16 & 2 & 0 & 43 & 6 & 15 & 14 & 5 & 3 & & & \\
\hline Absolut & 45 & 64 & 48 & 4 & 0 & 161 & 30 & 60 & 42 & 10 & 3 & 145 & & \\
\hline Rata-rata & & & & & & 3,74 & & & & & & 3,37 & 0,37 & 5 \\
\hline \multicolumn{15}{|l|}{ 5. Tangibles } \\
\hline Jumlah & 9 & 13 & 13 & 8 & 0 & 43 & 6 & 11 & 18 & 7 & 1 & & & \\
\hline Absolut & 45 & 52 & 39 & 16 & 0 & 152 & 30 & 44 & 54 & 14 & 1 & 143 & & \\
\hline Rata-rata & & & & & & 3,534 & & & & & & 3,325 & 0,205 & 1 \\
\hline
\end{tabular}

Dari perhitungan diatas maka dapat dinilai sikap anggota koperasi sebagai berikut:

$$
\begin{aligned}
\mathrm{Ab}= & 14,33(3,53-3,32)+11,46(3,67-3,46)+8,60(3,53-3,28)+5,73(3,58-3,26) \\
& +2,86(3,74-3,37) \\
= & 14,33(0,205)+11,46(0,209)+8,6(0,25)+5,73(0,32)+2,86(0,37) \\
= & 2,937+2,395+2.15+1,834+1,058 \\
= & 10,374
\end{aligned}
$$


Dengan skala interval dapat dilihat seperti pada gambar berikut ini:

\begin{tabular}{l} 
Sangat baik \\
\hline
\end{tabular}

10,374

Gambar 2: Hasil Perhitungan dalam skala interval

Sikap anggota koperasi "Sejahtera" Purwokerto terhadap atribut-atribut jasa pelayanan jika digolongkan ke dalam skala interval akan masuk dalam kelompok nilai yang berkisar antara 0 - 43 dan masuk dalam kategori sangat baik.

Berdasarkan perhitungan nilai sikap dengan menggunakan metode Multiatribut Atitude Model (MAM), maka hipotesis pertama yang menyatakan Sikap anggota koperasi terhadap atribut-atribut jasa pelayanan pada koperasi "Sejahtera" di Purwokerto baik ditolak, karena pada kenyataannya berdasarkan hasil analisis masuk dalam kategori sangat baik.

\section{Pengujian Hipotesis 2}

Untuk mengetahui diantara atributatribut manakah yang paling dominan, dilakukan dengan menganalisis nilai urutan tingkat kepentingan.

Tabel 6: Nilai urutan kepentingan

\begin{tabular}{|c|c|c|c|c|c|c|c|c|c|}
\hline \multirow{2}{*}{ No } & \multirow{2}{*}{ Atribut } & \multicolumn{5}{|c|}{ Urutan } & \multirow{2}{*}{ Resp } & \multirow{2}{*}{$\begin{array}{l}\text { Hasil } \\
\text { Total }\end{array}$} & \multirow[t]{2}{*}{ Urutan } \\
\hline & & 1 & 2 & 3 & 4 & 5 & & & \\
\hline 1 & Reliability & 9 & 6 & 13 & 10 & 5 & 43 & 125 & 1 \\
\hline 2 & Responsiveness & 5 & 6 & 15 & 10 & 7 & 43 & 137 & 3 \\
\hline 3 & Assurance & 6 & 6 & 14 & 11 & 6 & 43 & 134 & 2 \\
\hline 4 & Emphaty & 4 & 8 & 8 & 15 & 8 & 43 & 144 & 5 \\
\hline 5 & Tangibles & 5 & 6 & 14 & 11 & 7 & 43 & 138 & 4 \\
\hline
\end{tabular}

Sumber data: Data Primer diolah

Berdasarkan hasil perhitungan total yang digunakan untuk menentukan tingkat kepentingan yang diperoleh dari urutan tertentu terhadap suatu atribut dikalikan dengan banyaknya responden yang memilih urutan diperoleh nilai sebagai berikut:

$>$ Reliability: $(1 \times 9)+(2 \times 6)+(3 \times 13)+(4 \times 10)+(5 \times 5)=125$

$>$ Responsiveness: $(1 \times 5)+(2 \times 6)+(3 \times 15)+(4 \times 10)+(5 \times 43)=137$

$>$ Assurance $:(1 \times 6)+(2 \times 6)+(3 \times 14)+(4 \times 11)+(5 \times 6)=134$

Emphaty: $(1 \times 4)+(2 \times 8)+(3 \times 8)+(4 \times 15)+(5 \times 8)=144$

Tangibles: $(1 \times 5)+(2 \times 6)+(3 \times 14)+(4 \times 11)+(5 \times 7)=138$

Atribut reliability menduduki rangking pertama atau yang paling harus diperhatikan dalam melayani anggota koperasi dibandingkan dengan atribut yang lain karena mempunyai nilai yang paling kecil yaitu 125 . Urutan selanjutnya adalah assurance dengan nilai 134, Responsiveness dengan nilai 137, tangibles dengan nilai 138, dan yang paling terakhir adalah emphaty dengan nilai 144. Dengan demikian hipotesis yang 


\section{Kesimpulan}

1. Berdasarkan pengujian dengan menggunakan metode Multi atribute Attitude Model sikap anggota terhadap jasa pelayanan yang diberikan oleh pengurus koperasi "Sejahtera" di Purwokerto masuk dalam nilai skala interval sangat baik. Hipotesis pertama yang menyatakan Sikap anggota koperasi terhadap atribut-atribut jasa pelayanan pada koperasi "Sejahtera" di Purwokerto baik ditolak, karena pada kenyataannya berdasarkan hasil analisis masuk dalam kategori sangat baik.

2. Berdasarkan urutan kepentingan menurut penilaian anggota koperasi Atribut reliability menduduki rangking pertama selanjutnya adalah assurance, Responsiveness, tangibles dan yang paling terakhir adalah emphaty. Berdasarkan urutan tersebut maka hipotesis yang menyatakan atribut Emphaty yang paling dominan dari atribut-atribut yang ada pada atribut jasa pelayanan pada koperasi "Sejahtera" di Purwokerto, ditolak karena yang paling dominan atribut reliability.

\section{Implikasi}

1. Koperasi "Sejahtera" di Purwokerto dalam melayani para anggotanya sebaiknya memperhatikan atributatribut reliability, assurance, responsiveness, tangibles dan emphaty.

2. Atribut reliability menjadi atribut yang sangat penting untuk diperhatikan oleh pengurus koperasi, hal ini berkaitan dengan kemampuan para pengurus dalam memberikan pelayanan dengan segera dan memuaskan sesuai dengan yang telah dijanjikan.

\section{Daftar Pustaka}

Arikunto, Suharsimi, 2002, Prosedur Penelitian Suatu Pendekatan Praktis,PT. Bina Aksara, Jakarta.

Anoraga, Panji. 2000, Manajemen Bisnis, Rineka Cipta, Jakarta

Del. Hawkins, Roger J.Best. And Kenneth A. Coney, 1983, Consumer Behaviour Implication For Marketing Strategi, Business Publication, Inc, Texas.

http://pustaka.unpad.ac.id/wpcontent/uploads/2011/02/partisipasi_anggota_dan_dinamika_per -kembang.pdf

Kotler, Phillip, 2005, Straegi Pemasaran, Preshallindo, Jakarta

Parasuraman, A., Zeithaml, V.A dan Berry, L.L.,1994, "Reassessment of Expectations as a Comparison Standart in Measuring Service Quality : Implication for Further Research", Journal of Marketing, January ,111:124.

------- , 1988, “SERVQUAL: A Multiple-Item Scale for Measuring Consumer Perceptions of Service Quality”, Journal of Retailing, Vol.4 (1).

-------- , 1885, “A Conceptual Model of Service Quality and It's Implications for Future Research”, Journal of Marketing, Vol.4, p. 41-50. 
Supranto, J. M.A, 2003, Perilaku Konsumen: Teori dan Penerapannya, Rineka Cipta, Jakarta

Singarimbun, M dan Effendi, Soffian, 1995. Metode Penelitian Survey, LPES, Jakarta

Sugiyono, 2003, Metode Penelitian Bisnis, Alfabeta, Bandung.

Siti Partini, 1995, Psikologi Sosial, Studying, Jakarta

Stanton William, J, 1998. Prinsip Pemasaran, Gramedia, Jakarta

Swasta Basu DH dan Handoko T.Hani, 1997. Manajemen Pemasaran Analisa Perilaku Konsumen, Liberty, Yogyakarta

Schifman, L.G., Kanuk, L.L., "Perilaku Konsumen”, edisi ke tujuh, Jakarta, PT. Index, 2004

Tjiptono Fandy, 2008 “Strategi Pemasaran”, Edisi 3, Andi, Yogyakarta

Umar, Husein, 2002, Riset Pemasaran dan Perilaku Konsumen, PT. Gramedia Pustaka, Jakarta.

Wijaya Tony, (2011), Manajemen Kualitas Jasa (Desain Servqual, QFD dan Kano Disertai Contoh Aplikasi dalam Kasus Penelitian), Cetakan 1, Jakarta Barat 